\title{
Effect of vitamins A, E, C and omega-3 fatty acids supplementation on the level of catalase and superoxide dismutase activities in streptozotocin-induced diabetic rats
}

\author{
Tabei SMB ${ }^{1}$, Fakher $\mathrm{S}^{2}$, Djalali $\mathrm{M}^{2}$, Javanbakht $\mathrm{MH}^{2}$, Zarei $\mathrm{M}^{2}$, Derakhshanian $\mathrm{H}^{2}$, \\ Sadeghi MR ${ }^{3}$, Mostafavi E ${ }^{4}$, Kargar F
}

Department of Biochemistry, Shiraz University of Medical Sciences, Shiraz, Iran. drkargarf@gmail.com

\begin{abstract}
Background: Since free radicals and antioxidant enzymes may play an important role in the development of diabetes, the present study was designed to assess the effect of supplementation with vitamins $A, E$ and $\mathrm{C}$ and $\omega-3$ fatty acids on catalase and superoxide dismutase activity in streptozotocin (STZ)-induced diabetic rats. Methods: A total of 64 male Wistar rats weighing $250 \mathrm{~g}$ were divided into four groups as normal control, diabetic control, diabetic supplemented with vitamin A, E and C and diabetic supplemented with $\omega-3$ fatty acids. After four weeks the rats were anesthetized and catalase (CAT) and superoxide dismutase (SOD) activities were investigated in blood samples, liver and heart homogenates.

Results: In diabetic rats, the activity levels of heart SOD $(p<0.001)$ and heart and liver CAT $(p<0.001)$ were significantly lower than in normal control rats. Supplementation with vitamins $A, E$ and $C$ significantly increased heart CAT $(p=0.05)$. No significant change was observed in diabetic rats supplemented with $\omega-3$ fatty acids. Conclusion: Supplementation with vitamins $A, E$ and $C$ and $\omega-3$ fatty acids was found to increase heart CAT activity in diabetic rats and they can be valuable candidates in the treatment of the complications of diabetes (Tab. 6, Ref. 26). Text in PDF www.elis.sk.

Key words: vitamin C, vitamin E, vitamin A, $\omega-3$ fatty acid, catalase, superoxide dismutase.
\end{abstract}

\section{Introduction}

Diabetes is widely known to induce metabolic derangement leading to oxidant-antioxidant imbalance. The putative role of reactive oxygen species (ROS) in the development of diabetic complications has been investigated for several decades $(1,2)$. Propagation of lipid peroxidation is a degenerative process that affects cell membranes and other lipid-containing structures under conditions of oxidative stress, often with cytopathological consequences (3). Eukaryotic cells are equipped with a variety of primary and secondary defenses against the deleterious effects

${ }^{1}$ Department of Biochemistry, Shiraz University of Medical Sciences, Shiraz, Iran, ${ }^{2}$ Department of Nutrition and Biochemistry, School of Public Health, Tehran University of Medical Sciences, Tehran, Iran, ${ }^{3}$ Department of Reproductive Endocrinology \& Embryology, Avesina Research Institute, Tehran, Iran, ${ }^{4}$ Department of Pathology, Tehran University of Medical Sciences, Tehran, Iran, and ${ }^{5}$ Rajaie Cardiovascular Medical \& Research Center, Iran University of Medical Sciences, Tehran, Iran

Address for correspondence: F. Kargar, MD, Rajaie Cardiovascular Medical \& Research Center, Valiasr Street, Postal code: 1996914151, Tehran, Iran.

Phone/Fax: +982122042037

Acknowledgements: This study was financially supported by Tehran University of Medical Sciences. The authors wish to thank all corresponding personnel of nutrition and biochemistry department and animal house of Shiraz University of Medical Sciences. The authors declare that they have no conflict of interests. of oxidative stress. As lethal injury can occur when these defenses are overwhelmed, supplementation with antioxidant vitamins such as vitamins A, E and C may be beneficial (4). Vitamin E is a hydrophobic antioxidant found in lipoproteins and membranes and can afford primary as well as secondary stage protection. It is the most efficient scavenger of lipid peroxyl radicals (5). Vitamin C is a hydrophilic molecule that can scavenge several radicals, among them the hydroxyl radical. It is likely that vitamins $\mathrm{E}$ and $\mathrm{C}$ act in a synergistic manner, by vitamin E primarily being oxidized to the tocopheroxyl radical and then reduced back to tocopherol by vitamin C (6). Vitamin A plays an important role in insulin response as well (7). Supplementation with $\omega-3$ fatty acids can be useful to prevent diabetic complications. Long-chain $\omega-3$ fatty acids are incorporated into cell membranes and have anti-inflammatory properties that may be relevant for the prevention of type 1 diabetes, such as decreased expression of HLA class II molecules on activated human monocytes and reduced expression of interleukin $1 \beta(8,9)$. The long-chain $\omega$-3 fatty acids play an important role in eicosanoid metabolism, and there is evidence for aberrant prostaglandin metabolism in children with type 1 diabetes (10). Taken together, these data suggest that anti-inflammatory $\omega-3$ fatty acids such as DHA and EPA may reduce the risk of disease development. Thus the present study was designed to assess the effects of supplementation with vitamins $\mathrm{A}, \mathrm{E}$ and $\mathrm{C}$ and $\omega-3$ fatty acids on catalase and superoxide dismutase activities in the liver, heart and blood of streptozotocin-induced diabetic rats. 


\section{Materials and methods}

Animals and diets

64 male Sprague-Dawley rats (15-wk-old) weighing $250 \mathrm{~g}$ were used in this study. The rats received standard chow diet and water ad libitum during the experimental period, and were maintained at an environmental temperature of $18-23^{\circ} \mathrm{C}$ and $12-\mathrm{h} \mathrm{light/}$ dark cycle. The rats were randomly divided into four groups of 16 rats each, as normal control, diabetic control, diabetic rats supplemented with vitamins $\mathrm{A}, \mathrm{E}$ and $\mathrm{C}$ and diabetic rats supplemented with $\omega-3$ fatty acids. The rats in the normal control group received only standard diet and water. In the other three groups, diabetes was induced by intravascular injection of a single dose of STZ (40 $\mathrm{mg} / \mathrm{kg}$ body weight). Only those animals with blood glucose level over $300 \mathrm{mg} / \mathrm{dl}$ a week after injection were regarded diabetic. In the diabetic group supplemented with vitamins A, E and C each rat received $106 \mathrm{mg} / \mathrm{kg}$ vitamin A, $250 \mathrm{mg} / \mathrm{kg}$ vitamin $\mathrm{E}$ and 200 $\mathrm{mg} / \mathrm{kg}$ vitamin $\mathrm{C}$ daily by gavage. Each rat in the diabetic group supplemented with $\omega-3$ fatty acids received a daily dose of 300 $\mathrm{mg} / \mathrm{kg} \omega-3$ fatty acids by gavage.

\section{Tissue preparation}

After four weeks of intervention, the rats were anesthetized and arterial blood samples were collected in EDTA-containing tubes. After centrifugation of blood samples at $2500 \mathrm{rpm}$ for 5 minutes, the plasma was separated and erythrocytes were washed three times in $5 \mathrm{ml} 9 \% \mathrm{NaCl}$, total hemoglobin was measured and erythrocytes were stored at $-70{ }^{\circ} \mathrm{C}$ until biochemical analysis. Liver and heart tissues were promptly excised and washed with physiological saline, then dried by a filter paper and stored at $-70{ }^{\circ} \mathrm{C}$.

\section{Preparation of tissue homogenate}

For homogenate preparation to determine catalase and superoxide dismutase activities, 1:11 (W/V) tissue homogenate was prepared in $50 \mathrm{mM}$ potassium phosphate buffer ( $\mathrm{pH} 7.4), 150 \mathrm{mM}$ $\mathrm{KCl}$, and $200 \mathrm{mM}$ EDTA by a Potter-Elvehjem tissue homogenizer and then centrifuged at $15000 \mathrm{rpm}$ for 30 minutes. Protein concentration in the homogenate was determined by the Biuret assay using bovine serum albumin as standard (11).

\section{Catalase activity}

Catalase activity in liver and heart homogenates and erythrocytes was measured by Hygo Aebi method. In this method, the rate of hydrogen peroxide breakdown into water and oxygen is measured at $240 \mathrm{~nm}$ (12).

\section{Superoxide dismutase activity}

Superoxide dismutase activity in liver and heart homogenates and erythrocytes was measured with an indirect inhibition assay in which xanthine and xanthine oxidase produce superoxide radicals.

\section{Statistical analysis}

All values are expressed as mean \pm SD. Independent sample ttest was performed to compare the means of each two groups. A value of $p<0.05$ was considered to be statistically significant. All data were analyzed using Statistical Package for Social Sciences (version 11.5; SPSS Inc., Chicago, USA).

\section{Results}

The values and statistical comparisons of catalase and superoxide dismutase activity in experimental groups are shown in Tables 1 to 6 . Catalase activity was significantly decreased in the heart and liver of diabetic rats compared with control group $(\mathrm{p}<$ 0.001). In addition, supplementation with vitamins A, E and C caused a significant increase in heart catalase activity $(p=0.05)$. Supplementation with $\omega-3$ fatty acids made no significant change in catalase activity.

Superoxide dismutase activity was significantly decreased in the heart of diabetic rats compared with control group $(\mathrm{p}<0.001)$. Supplementation with vitamins A, E and C caused no significant change in heart superoxide dismutase activity in diabetic rats. Supplementation with $\omega$-3 fatty acids also made no significant change in superoxide dismutase activity.

Tab. 1. Values and the statistical comparison of catalase activity in normal control and diabetic control groups.

\begin{tabular}{lccc}
\hline Sample & $\begin{array}{c}\text { Normal Control } \\
\text { Group }\end{array}$ & $\begin{array}{c}\text { Diabetic Control } \\
\text { Group }\end{array}$ & t-test Results \\
\hline $\begin{array}{l}\text { Erythrocyte lysate } \\
(\mathrm{K} / \mathrm{mg} \mathrm{Hb})\end{array}$ & $145.63 \pm 21.36$ & $133.08 \pm 21.81$ & $\mathrm{p}=0.110$ \\
\hline $\begin{array}{l}\text { Liver } \\
(\mathrm{K} / \mathrm{mg} \text { protein })\end{array}$ & $407.10 \pm 99.24$ & $281.87 \pm 76.38$ & $\mathrm{p}<0.001$ \\
\hline $\begin{array}{l}\text { Heart } \\
(\mathrm{K} / \mathrm{mg} \text { protein })\end{array}$ & $57.80 \pm 11.94$ & $39.36 \pm 12.48$ & $\mathrm{p}<0.001$ \\
\hline
\end{tabular}

Data are presented as mean \pm SD. Each group contained 16 animals. The differences between groups were assessed by independent t-test. $\mathrm{p}<0.05$ considered significant.

Tab. 2. Values and the statistical comparison of catalase activity in diabetic control and diabetic + vitamins A, E, C groups.

\begin{tabular}{lccc}
\hline Sample & $\begin{array}{c}\text { Diabetic Control } \\
\text { Group }\end{array}$ & $\begin{array}{c}\text { Diabetic }+ \\
\text { Vitamins A, E, C } \\
\text { Group }\end{array}$ & t-test Results \\
\hline $\begin{array}{l}\text { Erythrocyte lysate } \\
\text { (K/mg Hb) }\end{array}$ & $133.08 \pm 21.81$ & $141.05 \pm 22.91$ & $\mathrm{p}=0.32$ \\
\hline $\begin{array}{l}\text { Liver } \\
\text { (K/mg protein) }\end{array}$ & $281.87 \pm 76.38$ & $315.98 \pm 70.43$ & $\mathrm{p}=0.19$ \\
\hline $\begin{array}{l}\text { Heart } \\
\text { (K/mg protein) }\end{array}$ & $39.36 \pm 12.48$ & $48.74 \pm 13.53$ & $\mathrm{p}=0.05$ \\
\hline
\end{tabular}

Data are presented as mean \pm SD. Each group contained 16 animals. The differences between groups were assessed by independent t-test. $\mathrm{p}<0.05$ considered significant.

Tab. 3. Values and the statistical comparison of catalase activity in diabetic control and diabetic $+\omega-3$ fatty acids groups.

\begin{tabular}{lccc}
\hline Sample & $\begin{array}{c}\text { Diabetic Control } \\
\text { Group }\end{array}$ & $\begin{array}{c}\text { Diabetic }+ \\
\omega-3 \text { fatty } \\
\text { Acids Group }\end{array}$ & t-test Results \\
\hline $\begin{array}{l}\text { Erythrocyte lysate } \\
\text { (K/mg Hb) }\end{array}$ & $133.08 \pm 21.81$ & $139.44 \pm 17.18$ & $\mathrm{p}=0.36$ \\
\hline $\begin{array}{l}\text { Liver } \\
\text { (K/mg protein) }\end{array}$ & $281.87 \pm 76.38$ & $311.24 \pm 75.26$ & $\mathrm{p}=0.28$ \\
\hline $\begin{array}{l}\text { Heart } \\
\text { (K/mg protein) }\end{array}$ & $39.36 \pm 12.48$ & $46.43 \pm 12.25$ & $\mathrm{p}=0.11$ \\
\hline
\end{tabular}

Data are presented as mean \pm SD. Each group contained 16 animals. The differences between groups were assessed by independent t-test. $\mathrm{p}<0.05$ considered significant. 
Tab. 4. Values and the statistical comparison of superoxide dismutase in normal control and diabetic control groups.

\begin{tabular}{lccc}
\hline Sample & $\begin{array}{c}\text { Normal Control } \\
\text { Group }\end{array}$ & $\begin{array}{c}\text { Diabetic Control } \\
\text { Group }\end{array}$ & t-test Results \\
\hline $\begin{array}{l}\text { Erythrocyte lysate } \\
\text { (Units/g Hb) }\end{array}$ & $898.45 \pm 91.68$ & $881.78 \pm 109.66$ & $\mathrm{p}=0.64$ \\
$\begin{array}{l}\text { Liver } \\
\text { (Units/mg protein) }\end{array}$ & $37.02 \pm 2.74$ & $35.96 \pm 3.12$ & $\mathrm{p}=0.31$ \\
\hline $\begin{array}{l}\text { Heart } \\
\text { (Units/mg protein) }\end{array}$ & $64.67 \pm 6.41$ & $50.21 \pm 6.42$ & $\mathrm{p}<0.001$ \\
\hline
\end{tabular}

Data are presented as mean \pm SD. Each group contained 16 animals. The differences between groups were assessed by independent t-test. $\mathrm{p}<0.05$ considered significant.

Tab. 5. Values and the statistical comparison of superoxide dismutase in diabetic control and diabetic + vitamins A, E, C groups.

\begin{tabular}{lccc}
\hline Sample & $\begin{array}{c}\text { Diabetic Control } \\
\text { Group }\end{array}$ & $\begin{array}{c}\text { Diabetic }+ \\
\text { Vitamins A, E, C } \\
\text { Group }\end{array}$ & t-test Results \\
\hline $\begin{array}{l}\text { Erythrocyte lysate } \\
\text { (Units/g Hb) }\end{array}$ & $881.78 \pm 109.66$ & $887.20 \pm 85.29$ & $\mathrm{p}=0.87$ \\
\hline $\begin{array}{l}\text { Liver } \\
\text { (Units/mg protein) }\end{array}$ & $35.96 \pm 3.12$ & $36.43 \pm 3.51$ & $\mathrm{p}=0.69$ \\
\hline $\begin{array}{l}\text { Heart } \\
\text { (Units/mg protein) }\end{array}$ & $50.21 \pm 6.42$ & $50.47 \pm 9.14$ & $\mathrm{p}=0.92$ \\
\hline
\end{tabular}

Data are presented as mean \pm SD. Each group contained 16 animals. The differences between groups were assessed by independent t-test. $\mathrm{p}<0.05$ considered significant.

Tab. 6. Values and the statistical comparison of superoxide dismutase in diabetic control and diabetic $+\omega-3$ fatty acids groups.

\begin{tabular}{lccc}
\hline Sample & $\begin{array}{c}\text { Diabetic Control } \\
\text { Group }\end{array}$ & $\begin{array}{c}\text { Diabetic }+ \\
\omega-3 \text { Fatty } \\
\text { Acids Group }\end{array}$ & t-test Results \\
\hline $\begin{array}{l}\text { Erythrocyte lysate } \\
\text { (Units/g Hb) }\end{array}$ & $881.78 \pm 109.66$ & $883.69 \pm 97.10$ & $\mathrm{p}=0.95$ \\
\hline $\begin{array}{l}\text { Liver } \\
\text { (Units/mg protein) }\end{array}$ & $35.96 \pm 3.12$ & $37.01 \pm 2.76$ & $\mathrm{p}=0.32$ \\
\hline $\begin{array}{l}\text { Heart } \\
\text { (Units/mg protein) }\end{array}$ & $50.21 \pm 6.42$ & $54.10 \pm 7.32$ & $\mathrm{p}=0.12$ \\
\hline
\end{tabular}

Data are presented as mean \pm SD. Each group contained 16 animals. The differences between groups were assessed by independent t-test. $\mathrm{p}<0.05$ considered significant.

\section{Discussion}

This experimental study on STZ-induced diabetes mellitus revealed that catalase activity decreased substantially in the heart and liver while superoxide dismutase activity decreased in the heart. In addition, supplementation with vitamins increased the catalase activity in the heart of diabetic rats. Supplementation with $\omega-3$ fatty acids made no significant change in catalase activity. The catalase activity of liver and kidney is reported to be decreased in most of the current literature on diabetic subjects (13, 14). Glucose auto-oxidation, protein glycation, and interaction of advanced glycation end-products with their specific receptors on macrophages are the main mechanisms of increased production of oxygen free radicals in diabetes $(15,16)$. In diabetic patients, the $\beta$ oxidation of fatty acids increases as a result of insufficient insulin level, and causes accumulation of hydrogen peroxide in tissues, thus leading to enzyme inactivation through glycation process. Since the concentration of hydrogen peroxide in the tissues is higher than that in the blood, the enzyme inactivation through glycation is more obvious in the tissues (17). The lipid/protein ratio in the heart is higher than those in the liver and blood, and it might be the reason of higher level of $\beta$ oxidation of fatty acids and hence higher level of hydrogen peroxide concentration which inactivates the enzymes of this tissue. It seems that applied vitamins act synergistically, and a combination of them provides a better effect. The ability of ascorbic acid to reduce $\alpha$-tocopheroxyl radical to generate $\alpha$-tocopherol and possibly to inhibit oxidation induced by $\alpha$-tocopheroxyl radical has been demonstrated in many in vitro and in vivo studies $(18,19)$. The synergistic effect of vitamins $C$, $\mathrm{E}$ and $\mathrm{A}$ could be expected based on the different environments where they act. Increased oxygen free radical production lowers the intracellular magnesium concentration and, in light of such evidence, vitamin $\mathrm{E}$ administration might also regulate the intracellular magnesium level. Vitamin $\mathrm{C}$ acts in the hydrophilic milieu by scavenging reactive oxygen species (20). However, in the hydrophobic domains of the bilayer, $\alpha$-tocopherol and vitamin A, will inhibit the lipid oxidation free radical chain reaction, and $\mathrm{Zn}$ located in the interphase of the bilayer will prevent iron or copper binding to the membrane $(21,22)$. Previously it has been reported that supplementation with vitamin $\mathrm{E}$ and vitamin $\mathrm{C}$ increases the activity of antioxidant enzymes (23). Supplementation with $\omega-3$ fatty acids might also increase antioxidant enzymes activity (24). Although the specific biologic mechanism for the beneficial effects of $\omega-3$ fatty acids on oxidative status has not been fully established, several data indicate that $\omega-3$ fatty acids may play a key role in decreasing the complications of diabetes $(25,26)$.

In conclusion, the results of the present study indicated that in diabetic patients, a combination of vitamins may increase the activity of antioxidant enzymes by decreasing free radicals production or inhibiting their oxidative damage. Further studies are needed to clarify the cellular mechanisms of this effect.

\section{References}

1. Maritim A, Sanders R, Watkins J. Diabetes, oxidative stress, and antioxidants: a review. J Biochem Mol Toxicol 2003; 17 (1): 24-38.

2. Rahimi R, Nikfar S, Larijani B, Abdollahi M. A review on the role of antioxidants in the management of diabetes and its complications. Biomed Pharmacother 2005; 59 (7): 365-373.

3. Uchida K. Future of Toxicology Lipid Peroxidation in the Future: From Biomarker to Etiology. Chem Res Toxicol 2007; 20 (1): 3-5.

4. Seven A, Guzel S, Seymen O, Civelek S, Bolayirli M, Uncu M et al. Effects of vitamin E supplementation on oxidative stress in streptozotocin induced diabetic rats: investigation of liver and plasma. Yonsei Med J 2004; 45 (4): 703-710.

5. Niki E, Noguchi N. Dynamics of antioxidant action of vitamin E. Accounts Chem Res 2004; 37 (1): 45-51.

6. Liu D, Shi J, Colina Ibarra A, Kakuda Y, Jun Xue S. The scavenging capacity and synergistic effects of lycopene, vitamin E, vitamin C, and $\beta$-carotene mixtures on the DPPH free radical. LWT-Food Sci Technol 2008; 41 (7): 1344-1349.

7. Berry DC, Noy N. Signaling by vitamin A and retinol-binding protein in regulation of insulin responses and lipid homeostasis. Biochimica et Biophysica Acta (BBA)-Mol Cell Biol Lipids. 2012; 1821 (1): 168-176. 
115-118

8. Norris JM, Yin X, Lamb MM, Barriga K, Seifert J, Hoffman M et al. Omega-3 polyunsaturated fatty acid intake and islet autoimmunity in children at increased risk for type 1 diabetes. J Amer Med Ass 2007; 298 (12): $1420-1428$.

9. Calder PC. Polyunsaturated fatty acids and inflammatory processes: new twists in an old tale. Biochimie 2009; 91 (6): 791-795.

10. Litherland S, Xie X, Hutson A, Wasserfall C, Whittaker D, She J et al. Aberrant prostaglandin synthase 2 expression defines an antigenpresenting cell defect for insulin-dependent diabetes mellitus. J Clin Invest 1999; 104 (4): 515-523.

11. Olson BJ, Markwell J. Assays for determination of protein concentration. Curr Protocol Protein Sci 2007: 3.4.1-3.4.29.

12. Aebi H. Catalase in vitro. Methods Enzymol 1984; 105: 121-126.

13. Shanmugam KR, Mallikarjuna K, Nishanth K, Kuo CH, Reddy KS. Protective effect of dietary ginger on antioxidant enzymes and oxidative damage in experimental diabetic rat tissues. Food Chem 2011; 124 (4): 1436-1442.

14. Schmatz R, Perreira LB, Stefanello N, Mazzanti C, Spanevello $\mathbf{R}$, Gutierres $\mathbf{J}$ et al. Effects of resveratrol on biomarkers of oxidative stress and on the activity of delta aminolevulinic acid dehydratase in liver and kidney of streptozotocin-induced diabetic rats. Biochimie 2012; 94 (2): 374-383.

15. Miyazawa T, Nakagawa K, Shimasaki S, Nagai R. Lipid glycation and protein glycation in diabetes and atherosclerosis. Amino Acids 2012; 42 (4): $1163-1170$.

16. Moheimani F, Morgan PE, van Reyk DM, Davies MJ. Deleterious effects of reactive aldehydes and glycated proteins on macrophage proteasomal function: possible links between diabetes and atherosclerosis. Biochimica et Biophysica Acta (BBA)-Mol Basis Dis 2010; 1802 (6): 561-571.
17. Giacco F, Brownlee M. Oxidative stress and diabetic complications. Circulat Res 2010; 107 (9): 1058-1070.

18. Yeum K-J, Beretta G, Krinsky NI, Russell RM, Aldini G. Synergistic interactions of antioxidant nutrients in a biological model system. Nutrition 2009; 25 (7): 839-846.

19. Niki E. Assessment of Antioxidant Capacity in vitro and in vivo. Free Rad Biol Med 2010; 49 (4): 503-515.

20. Bürzle M, Hediger MA. Functional and Physiological Role of Vitamin C Transporters. Curr Topic Membranes 2012; 70: 357.

21. Atkinson J, Harroun T, Wassall SR, Stillwell W, Katsaras J. The location and behavior of $\alpha$-tocopherol in membranes. Mol Nutrit Food Res 2010; 54 (5): 641-651.

22. Zago MP, Oteiza PI. The antioxidant properties of zinc: interactions with iron and antioxidants. Free Radic Biol Med 2001; 31 (2): 266-274.

23. Day R, Lal SS. Supplementation Effects of Vitamin C and Vitamin E on Oxidative Stress in Post Menopausal Diabetic Women. BioChemistry: An Indian J 2012; 6 (4).

24. Garrel C, Alessandri J-M, Guesnet P, Al-Gubory KH. Omega-3 fatty acids enhance mitochondrial superoxide dismutase activity in rat organs during post-natal development. Internat J Biochem Cell Biol 2012; 44 (1): 123-131.

25. McEwen B, Morel-Kopp M-C, Tofler G, Ward C. Effect of omega-3 fish oil on cardiovascular risk in diabetes. Diabet Educator 2010; 36 (4): 565-584.

26. Stirban A, Nandrean S, Götting C, Tamler R, Pop A, Negrean M et al. Effects of n-3 fatty acids on macro-and microvascular function in subjects with type 2 diabetes mellitus. Amer J Clin Nutrit 2010; 91 (3): 808-813. 